\title{
A. D. Jørgensen, skildret af en Søn
}

\section{Af Troels G. Jørgensen.}

Mange Aar er gaaet, siden min Far Historikeren A. D. Jørgensen $i$ Slutningen af forrige Aarhundrede afgik ved Doden, men hans Skrifter og øvrige Gerning er ikke blevet glemt. Til Oplysning om hans Personlighed og Livsgang har det heller ikke manglet paa Udtalelser, men allerede hvad der blev skrevet om ham af hans samtidige som af Troels-Lund, Marcus Rubin og Aage Friis, var i nogen Grad præget af manglende personlig Føling med ham, og endnu mere maatte dette gælde de Forfattere, der kun havde haft hans Skrifter og Breve at holde sig til. Det skete og kunde maaske ikke undgaas, at Fantasien paa visse Punkter blev taget til Hjælp, og Billedet af ham derved blev noget fortegnet. I $1897 \mathrm{blev}$ jeg, den tredjeældste af hans fem Børn, cand. jur., og jeg havde under hele min Uddannelsestid og indtil kort før hans Død 5. Oktober nævnte Aar altid boet hjemme og var den Gang 23/1/2 Aar gammel. De Erindringer, jeg derfor sidder inde med fra Hjemmet, vil gore det forklarligt - og jeg haaber give Berettigelse til - at jeg føler Lyst til at supplere tidligere givne Skildringer af min Far, og at gøre dette netop overfor Læserne af Sønderjydske Aarbøger.

Først nogle kortfattede Data om ham. Født 11. Juni 1840 gennemgik han først Folkeskolen i Graasten og kom derefter 1853 til den dansk-tyske Latinskole i Flensborg. Han forlod den i 1857 for at blive Landvæsenselev paa Avnbølgaard i Sundeved, men Aaret efter maatte dette opgives. Han vendte saa tilbage til Skolen, gik over i Realklassen og tog Afgangseks- 
amen 1859. Han tog derpaa til København paa den polytekniske Læreanstalt med matematiske Studier for $\emptyset$ je, men Undervisningen her ombyttede han snart med frie naturvidenskabelige og humanistiske Studier. I Marts 1863 blev han Hjælpelærer ved sin gamle Skole i Flensborg, og efter dens Lukning i Februar 1864 kom han paany til København. Her havde han siden 1860 ernæret sig som Lærer ved Schneekloths Skole, og 1869 ansattes han ved Statens Arkivvæsen. 1871 udgav han Bidrag til Nordens Historie i Middelalderen, 12 Afhandlinger, hvoraf omtrent Halvdelen havde været trykt allerede et Par Aar før. $1874 \mathrm{kom}$ den store Bog om den nordiske Kirkes Grundlæggelse og første Udvikling, og endnu i nogle Aar var hans Emner mest hentet fra Middelalderen. 1882 kom Fyrretyve Fortællinger af Fædrelandets Historie og af Arbejder i 1880-erne kan nævnes Biografier af Georg Zoega, Nils Stensen, Hans Adolf Brorson og Johannes Evald. I 1890-erne skrev han bl. a. Fortællinger af Nordens Historie, den store Bog om Peder Schumacher Griffenfeld og Afsnittet 1814-52 af Danmarks Riges Historie, hvortil et Forarbejde var Kong Kristian VIII og den danske Sag i Nordslesvig. Hertil kom Udgivelsen af Fru Heibergs Erindringer og Arbejder paa Arkivets Vegne. I dette naaede han i 1882 Chefposten som Gehejmearkivar fra 1889 Rigsarkivar.

I Forhandlingsprotokollen for det 1866 i København stiftede Sønderjydske Samfund - „den eneste kammeratlige Forening, jeg nogensinde blev Medlem af" -- hedder det 11. Marts 1869 om ham: „Formanden meddelte, at han snart agtede at indtræde i Egtestanden, og for at han kunde nyde Hvedebrødsdagene i Ro i det fjerne Vesten (Amerikas Mølle), vilde han fratræde sin Post." Den 24. s. M. ægtede han i Randers den 21-aarige Ida Marie Pedersen - en lang Forlovelse var gaaet i Forvejen - og de bosatte sig Vesterbrogade Nr. 146 ved "Sorte Hest“. Det var et af de sidste Huse paa Vesterbro, og "Amerikas Mølle" laa tæt ved, saa den spøgefulde Hentydning var natur- 
lig. Et Par Aar senere flyttede de endnu længere ud, nemlig til Bakkegaardsvej, som fra Vestre Fælledvej, der fra Vest førte til Vesterbrogade, gik op mod Valby Langgade med Forbindelse til J. C. Jacobsens Bryggeri Carlsberg. Tømrermester H. H. Kayser havde en Sommerbolig med stor Have ved V. Fælledvej. Derfra fik Far en Parcel, hvor Kayser opførte ham en rummelig Villa med Laage mellem de to Haver. I 1870-75 var der født fire Sønner og i 1880 en Datter, og til 1884 levedes der herude, som Far skriver, „12 lykkelige år i landlig ensomhed." Der var mere Mark end Bebyggelse, og Ny Carlsbergs. store Bygninger rejste sig først, da vi boede der, hvorpaa Vejen blev Ny Carlsbergvej. Der laa dog Aftapningsanstalten „Alliance“, og dette Fabriksanlæg ligesom det overfor vort Nr. 15 liggende Gluuds Sønners Garveri var tilligemed nogle Marker hørende til Bryggerierne og Kaysers Have samt længere borte Søndermarken en udmærket Tumleplads for „Jørgerısens Drenge“. Jeg nævner dette, fordi Far var meget liberal med, hvor og hvorledes vi tilbragte Fritiden, naar der da ikke kom Klager. I saa Fald og ved andre Lejligheder vidste vi, at det vilde blive til "Stryg" med Spadserestokken, thi saaledes var Traditionen for Opdragelsen af Drenge, i hvert Fald den sønderjydske, som vi levede under. Dette, der dog kun knytter sig til Minderne fra Ny Carlsbergvej, afsatte ikke „Komplekser“, men gav Holdningen en vis Undertone. Naar Far overlod os et vist Selvstyre, gav han sig heller ikke af med vore Foretagender, hverken Kaniner og Duer eller vore Haver. Det behøvedes ikke, da vi var fire, og han selv saa afgjort havde Brug for sine egne Tanker.

Men der var jo Sendagsudflugterne i samlet Familie! Det kunde være Skovture i Dyrehaven med Toget og helst i Vognens øverste Etage eller med Dampskib og med Besøg ved den slesvigske Sten, Eremitagen eller Fortunen. Turen til Damhussøen med Ophold i Kroen var ogsaa højt vurderet, skønt ret trættende med henved $9 \mathrm{~km}$ March. Mindre Ture gik til Forlystelseshavẹne „Sommerlyst“ og „Alleenberg« i Frederiksberg 
Alle, der bød paa et festligt Traktement af Salep. Den storste Begivenhed var Sommerferien i Graasten, hvor vi boede i Familieejendommen med Farveri, Strikkemaskiner og Manufakturforretning hos Onkel Asmus og Tante Anna med deres jævnaldrende Børn. Vi lærte Graastenersproget og tumlede os paa Søen og i Skoven. Bedsteforældrene boede $i$ et lille Hus ved "Palæet", hvor Bedstefar havde sin Drejebænk. Han døde 11. August 1883, og til den store Begravelse afrejste Far med min ældste Broder, der skulde bære hans Hæderstegn paa en Pude paa Vejen til Adsbel Kirke.

I det daglige var Børnenes Omgangsform overfor Far noget tilbageholdende, og ved Bordet forholdt vi os tavse. Far talte gerne om et eller andet belærende eller om egne Oplevelser, $f$. Eks. om sin Tid paa Avnbølgaard. Vi spiste jævnlig Boghvedegred til Minde om, at de dér omtrent ikke havde levet af andet. Det skete ogsaa, at han læste op for os, f. Eks. af Svend Grundtvigs eller Asbjørnsens Folkeeventyr eller af Oehlenschlæger, eller viste os Billeder $i$ sine Bøger. Han anvendte en Samling af plattyske Vendinger fra sin Tid i Flensborg, der udgjorde et eget humoristisk Sprog i Hjemmet. Kirkegang var ikke hans Skik. Med Far mindes jeg kun at have været i Kirke i Slotskapellet i Graasten. Et Par Gange om Ugen kunde man regne med, at han kom hjem og havde Hovedpine og derfor maatte hvile sig en Tid. Naar han tog sin sorte Kalot paa, vidste Børnene Besked, og der maatte da være særlig Stilhed. Denne Svaghed plagede ham i mange Aar, men var dog efterhaanden stærkt aftaget.

Med Omgivelserne i "det fjerne Vesten“ havde Forældrene ingen Forbindelse undtagen om Sommeren med Kaysers, hvor der var voksne Sønner og Døtre, og det var vistnok heller ikke mange Gæster, der kom til Huset, afsides som det laa, men jeg kan naturligvis ikke huske alle. Jeg husker dog et Selskab, der formentlig blev holdt sidst i 1882, da Far blev Gehejmearkivar, og hvor Historikeren Kr. Erslev, der 28. December fyldte 30 
Aar, var Genstand for Opmærksomhed. Jeg kan nævne Raadstuearkivaren Dr. Oluf Nielsen og Rigsdagsmanden Jokum Termansen. Iøvrigt havde vi Familiebesøg af Bedsteforældrene fra Graasten og Mormor samt to yngre Brødre af Mor, der ogsaa kunde overtage at gaa med os i Zoologisk Have og i Samlingerne.

Det var som en social Fremgang, da vi flyttede fra dette Kvarter, der efterhaanden blev bebygget for Bryggeriarbejderne, og fik Bolig paa Lindevej, en Sidevej fra Gl. Kongevej ,i Villaen Nr. 10, der var større men med mindre Have end den forrige. Til denne var Fars Velynder Brygger J. C. Jacobsen en gunstig Køber, medens Professor Adolf Steen solgte, fordi han havde faaet Professorbolig. Ogsaa her var ret landligt, da. Kvarteret var under Villaservitutter, og Strækningen ned til Værnedamsvejen, hvor Skolen laa, ret ubebygget. Landligt virkede det ogsaa, naar den hestetrukne Omnibus ad Gl. Kongevej til Kongens Nytorv meldte sit Komme ved det kgl. Teaters Spilletid med Hornsignal. Far tilbagelagde som tidligere Vejen til Arkivet og hjem til Fods, og normalt var det hans eneste Spadseretur, bortset fra Vejen fra Arkivet ved Christiansborg til Læseselskabet Athenæum i Hotel Royal, Ved Stranden, og paa Sommerdage lidt Spadseren i Haven. Han arbejdede ikke i denne, og da han efter Indflytningen vilde lufte ud i den tilgroede Have ved at save løs paa en stor Rødtjørns Grene, var det nær blevet for meget for ham; den Slags Arbejde laa ikke for ham.

Der var god Brug fon Pladsen i de 13 Aar, Far kom til at bo i Huset. Min næstældste Broder Erik (senere Erstad-Jørgensen) var 1888-92 borte som Gartnerelev og senere som Soldat, og min ældste Broder Adolf, der 1895 blev cand. polyt., fik Plads i Vejle og tog paa Studierejse i Amerika. Jeg var i 1897 nogle Maaneder paa Kaserne i Byen, men iøvrigt var vi hjemme, optaget af Skolegang og videregaaende Uddannelse, og fra 1892 havde en Halvkusine fra Norge Agnete Jürgensen, født 1883, 
faaet Ophold hos os, saa at Børnetallet var 6. Det var et Hus, hvor der blev arbejdet og for Ungdommens Vedkommende taget Eksaminer. Det var saa heldigt og skyldtes vel ogsaa Fars pædagogiske Blik og praktiske Sans, at alle fire kom til de for os egnede Fag, min yngste Broder Olav (O. E. Jørgensen) som cand. polyt. og senere Dieselekspert.

Arbejdsdagen for Far forløb saaledes, at han spiste Frokost hjemme efter at have arbejdet et Par Timer og derpaa gik til Arkivet. Kort efter, at han var kommen hjem, spistes der til Middag, og Forældrene holdt en Siesta ved Kaffen. Det kunde trække ud med, at Far laa paa Chaiselonguen eller gik op og ned ad Gulvet, men ellers satte han sig til Arbejde ved Skrivebordet i sin Stue, der i Reglen havde Døren aaben til Dagligstuen, hvor Mor opholdt sig. Kl. ca. 9 blev der drukket Te og efter fortsat Arbejde gik han i Seng vistnok Kl. 101/2, uden nogensinde at lade dette Klokkeslet blive forrykket af Travlhed. Tobak og (i det daglige) Spirituosa var ukendte Artikler for ham. Avislæsningen omfattede Nationaltidende, Flensborg Avis, Hejmdal, Tidens Strøm og Vort Forsvar, og inde i Athenæum, hvor han ogsaa dyrkede Bekendtskab med den gamle, blinde Journalist Giödwad, saa han andre Aviser og Tidsskrifter. Det kan siges, at Børnene ikke voldte ham særlige Bekymringer heller ikke med Sygdom og Svagelighed. Ogsaa Mor var rask, men han selv havde i Aarene op mod 1887 nogle Anfald af Blindtarmsbetændelse, der behandledes hjemme uden Operation. Om Turene til Graasten har jeg talt. I 1885 rejste han til Tyskland for at se paa de derværende Provinsarkiver og undersøge Papirspørgsmaalet og i 1889 til Norge (Kristiania og Trondhjem) for at se, hvorledes Stiftsarkiverne var indrettet. Bortset fra en lille Rekreationsrejse til Blekinge 1876 og en Tur til Kullen 1861 havde han ellers ikke været udenfor Landets Grænser og Sønderjylland. Noget betød det herved sikkert, at en Rejse kostede Penge, og paa sig selv anvendte han kun det helt paatrængende. Men hans stærke Drift til Begrænsning gjorde sig 
ogsaa gældende, ligesom med Hensyn til Læsning. Videnskabelig Litteratur læste han nærmest kun i Forbindelse med sin egen Produktion, og Underholdningslektyre følte han meget sjældent Lyst til. Han længtes imidlertid hvert Aar efter i Ferien at komme „hjem til Graasten“, men naar dete var sket, vilde han egentlig helst blive paa Lindevej og dele sig mellem Athenæum og Haven. Men her havde Mor sine Ønsker om en Husmoderferie, og Løsningen blev i Reglen et baade-og. Forste Gang i 1887 drejede det sig tillige om et Rekreationsophold efter Sygdom, og Stedet blev Aalsgaarde ved Hellebæk, hvor Fru Heiberg Aaret før havde boet. I 1889 var vi i Arildsläge, Aaret efter i Bisserup udfor Fænø, i 1891 i Arildsläge, 1893 i Espergærde og 1896 i Båstad. Far kunde meget godt en Tid hygge sig ved et ubeskæftiget dolce far niente, skønt han hverken havde Sport, Badning, Samlerinteresser eller Tobakken at adsprede sig med. Han lod i Ensomhed Refleksionens Fugle baske med Vingerne, passiarede eller anførte til Familieudflugt. I 1891, da jeg var blevet Student, gjorde Far med min ældste Broder og mig en længere Tur end sædvanlig i Sønderjylland. Med Udgangspunkt i Graasten var vi i Sønderborg, hvor vi traf Hanssen Nørremølle, og besøgte Dybbøl; derfra tog vi til Slesvig og Dannevirke, hvorfra Far medførte et Murstensstykke, og norapaa til Aabenraa i Besøg hos "Tante Bahnsen".

Far havde væsentlig kun to Steder for sit Virke. Først Arkivet, hvor han som 29-aarig havde faaet Ansættelse trods manglende Eksamen, fordi han var "fordreven Slesviger", og haabefuld ved sine første Afhandlinger. To Aar efter, at han havde faaet Chefstillingen, havde Arkivets Skatte heldig undgaaet Ødelæggelse ved Slotsbranden 3 . Oktober 1884, senere havde han et stort organisatorisk Arbejde, der i hans sidste Tid medførte Bryderier, der svækkede hans Sundhed. Dernæst var det Huset, hvor han foruden sin Plads i den store Familie, som han underholdt og levede med i, selv om han i nogen Grad „Svævede over Vandene“, arbejdede med sine frit valgte litte- 
rære Opgaver. Til Rejser i Indlandet i Arkivanliggender eller for at holde Foredrag paa Højskolerne i Vallekilde, Ryslinge, Testrup og Askov var der dog ikke sjælden Anledning, og ligeledes var der Bud efter ham som Foredragsholder i københavnske Foreninger. „Naar det drejer sig om, at man onsker Oplysning, siger jeg ikke nej," ytrede han en Gang om Henvendelsen fra en ikke videre anselig Forening.

At han havde Meninger om andet end Fortidens Skikkelser og ogsaa folte varmt for det samtidige: Forsvarssagen og Kampen om Landets Styrelse, gjorde han ingen Hemmelighed af. Hans Dagbog fra 1884-96 (Danske Magazin 7. R. 5. B. 1949) viser, at han i 1885 gjorde Forsøg paa at føre de politiske Forere sammen $i$ et Forlig om Finansloven, hvilket mislykkedes, hvorimod lignende Bestræbelser af ham i 1882 havde bidraget til at afværge en Sprængning (Tillæg til Brevudgave 1939 ved Harald Jørgensen). Som ung havde han ogsaa lagt sig i Selen for politiske Formaal, da han i 1865 rejste i Sionderjylland for at skaffe Oplysninger, der antagelig havde Betydning for Fremkaldelsen af Pragfredens $\S 5$, og i 1866 havde virket for den sønderjydske Adresse til Kong Wilhelm. I den lange forst i 1894 nogenlunde bilagte Strid mellem Højre og Venstre kunde han ikke give nogen af Parterne Ret, han havde personlige Forbindelser 1 begge Lejre og var opfyldt af dyb Lede ved denne altødelæggende Splid. Forsvarssagen, om end ikke den frivillige Selvbeskatning, var han derimod Tilhænger af. Lyst til at optræde som Politiker havde han ubetinget ikke. Heller ikke onskede han at blive ledende Senior i Studenterforeningen, hvor han var ekstraordinært Medlem og flere Gange havde talt. Jeg husker, at L. Moltesen en Aften selvanden kom og stillede ham Forslag herom, men han var straks klar over, at det ikke var noget for ham. I Almindelighed ansaas han vistnok for konservativ. I politisk Henseende var han det altsaa kun delvis, og naar han i Livssyn ansaas for at være Grundtvigianer, var der den Forskel, at han overhovedet stod udenfor det kirkelige. 
Hvad Hjemmets Omgangskreds angaar, havde kun Mor nogie fjernere Slægtninge i Byen. Selskabeligheden var da mest begrænset til Fars Kolleger med Familier og hans Ungdomsven Murmester Karl Kruse og dennes Søster Marie, Skolebestyrerinden, der stammede fra Flensborg. I senere Aar kom hertil Skuespiller Emil Poulsen og hans elskværdige Familie. Bekendtskabet var vistnok opstaaet gennem Fru Heiberg, og det faldt sammen med, at Far fik Fribillet til det kgl. Teater, hvor han ikke forsømte sine Aftener; i mange Aar havde han næsten ikke besøgt Teatrene. I flere Aar samlede Far ved Nytaarstid Arkivpersonalet, og Stemningen ved Middagen var altid udmærket. Men det kom ham for Øre, at en ældre af det underordnede Personale havde ladet sig forlyde med, at han fandt Afholdelsen af disse Sammenkomster tvungen, og saa brød han straks af for at nøjes med Omgangen med Bricka, Kringelbach, Secher og Thiset. Andre Omgangsfæller var Genboen Professor Camillus Nyrop, Bagermester Jacob Marstrand og Højskoleforstander F. Falkenstjerne. Andre Højskolefolk var Ernst Trier med sin altid sprudlende Tale og Christoffer Bågø, der var ligesaa faamælt. Sønderjyder og sønderjydsk interesserede kom til Forhandlinger undertiden i stort Antal. Med Gustav Johannsen følte han sig saa samstemmende, at de blev Dus. J. Jessen og H. P. Hanssen var meget forskellige, man kunde sammenligne dem med Henrik Ibsen og Bj. Bjørnson. Skønt Far ved sin Stilling til Forsvarssagen stod Jessen nærmere, var det dog Hanssen, han bedst samvirkede med ved Organiseringen af Vælgerforeningen og Skoleforeningen (1888 og 1892), og han bebrejdede Jessen ikke at ville samvirke heri. Bly og beskeden var $\mathrm{H}$. V. Clausen, den flittige Gransker af Tilstanden i Nordslesvig. Far betegnede i en Tale hans Iver som "rørende", og hvad der rorte ham, var vel, at den ikke-hjemmefødte havde kunnet knytte sig saa varmt til hans Hjemland. Johan Ottosen var fuld af Virkelyst, men for Resten ogsaa optaget af at informere sig hos Far til Brug for sine nye Lærebøger i Historie. Ogsaa Pro- 
fessor Høffding var en enkelt Gang Gæst ved en saadan Lejlighed. Endelig vil jeg nævne Skoleforstander, cand. theol. Johan Borup, der var en ret hyppig Gæst og gjorde Indtryk paa os Børn ved sin ivrige Optagethed af sine Emner: Højskolesagen og dansk Digtning. Han skrev til mig bl. a. (5. Oktober 1941): „Han var en af de første, jeg betroede mig til med mine højtflyvende, i Førstningen altfor højtflyvende Planer, og han hjalp mig ud af dette for højtflyvende. Han gik siden i Brechen for mig hos Nellemann ......

Jeg kunde fortælle meget om Deres Far. Jeg ser ham en Sommerdag i sort Klædes Frakke med svingende Skøder stryge ned ad Gl. Kongevej ud til Lindevej; jeg prajede, lagde til og vi talte sammen om et Digt af Hauch."

Med Skuespillerinden Fru Heiberg og Politikeren A. F. Krieger havde han til deres Død i 1890 og 1893 fra, omkring Midten af 1880-erne et Samarbejdsforhold, der personligt og arbejdsmæssigt kom til at betyde meget for ham og senere ogsaa for Offentligheden, da Fru Heibergs „Et Liv genoplevet i Erindringen" udgaves af ham kort efter hendes Død, og Kriegers polit1ske Dagbøger af andre ganske vist først efter mange Aars Forløb, se Ord och bild 1952.

For A. D. Jørgensen som Historiker var det ejendommeligt, at hans eget Liv var et Stykke af Fædrelandets Historie, ikike ved Bedrifter han havde udført, men fordi Oplevelser i hans Barndom og Ungdom, der skyldtes afgerende Kriser i Landets Historie, blev naturlige Forudsætninger for hans Historieskrivning. Treaarskrigens nationale Gennembrud i Sønderjylland havde betinget hans bevidste Valg af dansk Kultur fremfor den tyske, og han havde derfor søgt Uddannelse og Udvikling i Hovedstaden. Da saa Stormagtskrigen havde sprængt Helstaten og ført til Fraskillelse af store Dele af det danske, maatte det blive en naturlig Reaktion indenfor disse Dele at efterforske Aarsagerne til Fraskillelsen og Ansvaret derfor, og efter hans særlige Anlæg blev det ham, der tog denne Opgave op. Dette 
blev tillige hans egen Historie. I hans i Foraaret 1896 nedskrevne „En redegørelse for min udvikling og mit forfatterskab," som hans Efterladte udgav 1901, har han paavist denne Sammenhæng, og samtidig har det været ham magtpaaliggende at faa frem, at han ikke følte sig forpligtet til „egentlig“ Historieforskning ud over dette. I disse Aarbøger for 1899 skrev Johan Ottosen en Mindeartikel, der er beundringsværdig ved sin Forstaaelse, i Betragtning af, at hverken Redegørelsen, Brevene eller Dagbogen forelaa. Ottosen oplyser da ogsaa, at han i 1894 havde faaet meddelt Levnedsløbet i en Samtale med Far, som han nedskrev, og at han havde faaet Oplysninger fra gamle Venner af ham, f. Eks. Professor Matzen. Hertil kom Ottosens egne Indtryk, der bl. a. viser, at det ikke blot var Familien, der havde Erfaring for, at A. D. Jørgensen kunde frigøre sig humoristisk overfor andre. Jeg husker f. eks. et Møde - for Resten det samme, hvor Ottosen vistnok for første Gang lod synge „Det haver saa nyligen regnet", som han selv spillede til, - hvor han stod op og uden Indledning paa Sundevedmaal fortalte nogle komiske Landsbyhistorier. H. P. Hanssen var i den syvende Himmel. I sin iøvrigt saa sympatiske Omtale af ham (Illustreret Tidende 15. Sept. 1901) havde Troels-Lund fremhævet det modsatte.

Jeg griber her Lejligheden til at meddele to Stykker af Redegørelsen, omhandlende den sønderjydske Bevægelse i Hovedstaden, som ved Trykningen blev udeladt, iøvrigt paa Foranledning af Ottosen, der var Konsulent for Nordisk Forlag. De Grunde, som kunde tale herfor, er sikkert ikke mere tilstede. Vedkommende Sted i Redegørelsen. S. 154, faar følgende Indhold, naar det tilføjede anbringes i [ ].

„Mine indlæg i forsvarssagen og særlig min optræden ved et fra venstre side sammenkaldt almindeligt studentermøde $i$ „Føniks“ (10. Sept. 1887) gav endog nærmest anledning til, at jeg blev skudt stærkt i forgrunden i den straks efter påfølgende bevægelse for den sønderjydske sag i studenterkredse. [Kand. 
Joh. Ottosen, der havde en levende interesse for denne fra et længere ophold paa Ærø og kand. H. V. Clausen fra Odense, der lige fra drengeårene havde haft samme interesse, fik i studentersamfundet en kraftig forbundsfælle i H. P. Hanssen fra Nørremelle i Sundeved, der med ungdommelig ild og med sin klare forstandighed påvirkede adskillige af de radikale mænd, der så småt begyndte at kedes ved den evindelige tale mod provisoriet. De indbød Gustav Johansen og mig til en selskabelig sammenkomst på St. Thomas i Frederiksberg alle (16. Sept. 1887) og her drøftede vi da til langt ud på natten det nationale spørgsmål med Ottosen, Høffding, Neergaard, Rubin, Philipsen, Herman Trier, H. Bing, Erik Skram, Kr. Erslev, Clausen, Hanssen Nørremølle o. a.; de oprettede kort efter foreningen „4 S“ (studentersamfundets sj. samfund) med det formål at skaffe den nyere danske litteratur indgang derovre. Nordslesvig skulde „demokratiseres*, som det hed; jeg forsikrede forgæves, at det alt var demokratisk sindet nok. En tilbageerobring af det tabte danske land vilde de dog foreløbig ikke høre tale om, da Tyskland var bærer af den højeste kultur og en svækkelse af dennne magt derfor ikke at ønske.

I det følgende år gav imidlertid den unge tyske kejsers besøg i udstillingen anledning til en række tyskvenlige artikler i „Politiken", og dette bidrog til at klare vore venners anskuelser; de fleste af de nævnte mænd erklærede sig nu rede til at deltage $i$ et offentligt møde, ved hvilket man vilde nedlægge indsigelse herimod og udtrykte sin deltagelse og taknemmelighed overfor den danske befolkning $\mathrm{i}$ Nordslesvig. Dette blev dog forhindret ved kongens personlige indgriben, men stemningen var nu vakt og der dannedes en forening under navnet "to løver" i den gamle studenterforening med advokat Nellemann, der havde tilbudt at dirigere det påtænkte møde, som formand. Jeg opfordredes til at indtræde $i$ bestyrelsen som forbindende mellemled med „4 S“, og den 31 . Oktober 1888 holdt vi vort åbningsmøde $i$ foreningen; 5 . November kom de to bestyrelser sammen, og 
det besluttedes at arbejde $\mathrm{i}$ fællesskab. Mit program, at udgive et tidsskrift og oprette en større bogsamling, med fast ansat bibliotekar, vedtoges og blev kort efter sat i værk; „Sønderjydske årbøger" udkom fra det følgende års begyndelse med Hanssen Nørremølle som redaktør. Jeg havde først tænkt på Jessen i Flensborg og skrevet til ham om det (alt i 1886), men hans tåbelige fjendskab mod Hanssen, hvis navn han ikke vilde tåle ved siden af sit eget, førte til et brud, som ikke senere heledes. Derimod] kom jeg atter [ved organisationen af de nye foreninger] i fuld forståelse med Monrad, som selv var kommen til den overbevisning, at man nu måtte udvide sin virksomhed og ikke kunde afvise et samarbejde med venstremænd. Desværre døde han kort efter; han var en af de mest trofaste mænd, som har kæmpet for danskhedens sag i Nordslesvig.

[Efter oprettelsen af disse foreninger tog arbejdet for den nationale sag et synligt opsving både her og der; dẹ betydningsfulde virksomhed, som Hanssen Nørremølle i de følgende [år] udførte, havde sit gode rygstød i os. Jeg var selv, især i den første tid, stærkt optagen; 14. Juni 1889 gjorde vi det første forsøg på at samle mænd af begge partier til et fællesmøde; det var i Holbæk, hvor den utrættelige Villars Lunn (Knabstrup) fik dette sat i scene; der blev dannet en forening med mænd af begge partier $i$ bestyrelsen. Mit foredrag ved denne lejlighed „om kampen for den danske nationalitets bevarelse i Nordslesvig." blev senere trykt og udbredt i 20.000 eksemplarer. I September s. å. lejede vi Kasinos store sal til et møde med Gustav Johansen som hovedtaler og også her mødtes folk fra alle lejre. I foråret 1890 begyndte vi endelig den række møder, der senere fortsattes, med forhandlinger med førerne fra Nordslesvig om de foretagender, vi kunde tænke os at sætte i værk, og drøftelser af den fælles sag; derpå fulgte et større møde med alle dem af vore foreningsmedlemmer, som ,vilde deltage. „To løver" og „4 S“ optrådte ved denne lejlighed i nøje forbindelse med det ældre „sønderjydske samfund“, der vedblev at bestå som fore- 
dragsforening, og med Kayser og hans nærmeste venner („Dannebrog"). Der var her grundlagt en organisation, som på mange måder spåede godt for fremtiden; den samtidige udvikling i Tyskland efter Bismarcks fald var et yderligere held for vor sag.]"

Den Sønderjyllands Historie, hvori han fra først af havde tænkt sig at lægge hele sit Arbejde, blev ikke noget samlet udarbejdet Værk; et stort Manuskript ført op til det 18. Aarhundrede (affattet 1866 og 1879-81) findes i Rigsarkivet. Udarbejdelsen af de 40 Fortællinger, der særlig var beregnet paa Udbredelse dernede (bekostet af Brygger J. C. Jacobsen) kom imellem, og Forfatteren maatte nøjes med at indarbejde sit indsamlede Stof i denne Bog. Efter det særlige Formaal, han forfụlgte, kunde han ikke hæfte sig ved en enkelt Tidsalder og gøre sig til Specialforsker af denne, men han maatte have hele Ud. viklingslinien med. Naar han ikke senere tog sin oprindelige Plan op, har det maaske ogsaa været, fordi det samlede Rige maatte være det rigtige Emne for ham, selv om han fastholdt sit særlige Sigte. Det var tillige hans Hensigt at gaa til Bunds i Undersøgelserne, og ogsaa dette maatte føre ham til at begynde ved den første historiske Tid og sysle med de ældste skriftlige Kilder, selv om de særlige sønderjydske Problemer med de fyrstelige Rettigheder over Landsdelen, Forbindelsen med Holsten og Fortyskningen endnu ikke da havde meldt sig. Disse Arbejder præges af, at Forfatteren ikke gjorde sig disse Bekymringer, men kunde dyrke Glæden ved at skabe nyt Udsyn og ved at fortælle. Ikke mindst kommer det sidste frem i Hovedværket Kirkehistorien, der ogsaa fængslede ham som Aandshistorie, idet et tidligere Yndlingsemne for ham havde været den hedenske Gudelære. Ligesom han i sin mundtlige Form var helt fri for Dialekt ikke blot i Ordvalg men i Betoning, medens denne var kendelig hos andre af hans tidligere Kammerater fra Flensborg som Departementschef Asmussen og Professor Matzen, var hans skriftlige Stil den reneste rigsdanske, men dog med et umiskendeligt per- 
sonligt Præg. Det laa ikke i Ordvalget, da han ikke var enig i de egentlige Sprogrenseres Bestræbelser og kun brugte enkelte særprægede Gloser, men i hans Maade at henvende sig paa til sine Læsere. Han skrev i Forordet til sin første Bog, idet han hævdede Afhandlingernes fulde Videnskabelighed, at de dog var affattet med det Maal for $\emptyset$ je at være tilgængelige for enhver dannet Læser uden Kendskab til de benyttede Kilders Sprog, „og forf. vilde anse det for den største personlige tilfredsstillelse, om sådanne læsere kunde føle sig tiltalte af fremstillingen“. Som Foredragsholder havde han øvet sig i Sønderjydsk Samfund overfor et saadant Publikum. Endvidere præges Stilen af hans Indtrængen i Emnet. Han slaar ikke af paa Fordringerne til nøjagtig Udtryksmaade og kan forsaavidt virke tør, idet han heller ikke kæler for Læserne med Billeder og blomstrende Vendinger, men han belønner Opmærksomheden med en fyndig og smukt formet Vending, der ved Slutningen slaar Resultatet fast.

Biografierne, der alle omhandler Aandspersonligheder, forte ham hen til Enevældens langt senere Tidsrum, og i sin storste Personskildring, Bogen om Griffenfeld, redegjorde han for Enevældens Opkomst og første Tid. Aftalerne om at deltage i Samlingsværket Danmarks Riges Historie var trufne, inden denne Bog var færdig, saa Behandlingen af Opgøret om 1864, der skulde være den afsluttende Akt i Dramaet, stundede til. Hans Personskildringer havde $\varnothing$ je ogsaa for Skyggesiderne hos hans Emner. I det daglige havde han ligeledes for megen Humor til kun at beundre eller kun at se Vrangsider, og det ene udelukkede slet ikke det andet. Overbærenheden fik Udtryk i denne Sætning i Kirkehistorien S. 716: „Kærligheden skjuler syndernes mangfoldighed ved at lægge dem for dagen i hele deres dybe sammenhæng med menneskenaturen". Noget anderledes forholdt det sig med Bedømmelsen af Griffenfeld, mod hvis Karakter cg Moral han rejste stærkere Anker end før sket, og dog mindede han til sidst om Fortællingen om Drengen, der var saa lykkelig at have et Guldæble i sin Haand, og berørte hans store Ev- 
$n \in r$ og Sammentræffet med hans historiske Situation. Deri fandt en senere Forfatter en ,skærende Modsætning til Bogens Indhold" og udkastede den barokke Tanke, at „de skønne Slutningsord“ var nedskrevet før Bogens Begyndelse (Knud Fabricius' Bog om G. 1910). Den ikke ugunstige Læser vilde dog have bemærket, at der først havde været talt om Instrumentet, der efter at være knust faar renere Klang. Tanken var altsaa, at den "stakkels livsfange“ havde sonet sine moralske Brøst og derfor $n u$ kan ses fra Lyssiden.

Med Vilje og Evne til ligelig Bedømmelse og til at gøre Ret og Skel gik han derfor til sit Hovedemne at vurdere Tilblivelsen af den frie Forfatning og Livet under denne til 1864. Nu vil enhver politisk Retning, som har Magten, være bestræbt paa i Litteraturen, først Dagspressen siden Bøgerne, at forsvare sine Handlinger, erhverve Anerkendelse for sine Personligheder og undertrykke Indsigelser. Dette efterlades saa Eftertiden til at leve videre paa. Saaledes havde det været Tilfældet med Nationalliberalismen, da Arbejdet med at skildre denne fra et nyt Synspunkt toges op 30 Aar efter Krigen. Den Mand, han havde lært saa meget af, A. F. Krieger, og Th. A. J. Regenburg, hvem han højagtede, var nylig gaaet bort, og det følte han som en Lettelse, da hans Angreb, hvortil hørte en højere Vurdering af Christian VIII, maatte blive skarpt. To Citater vil lettest føre Problemerne frem, som de tegnede sig for ham. I Dagbogsoptegnelsen af 21. Juli 1895 siger han om Bismarcks Fordring i 1864 paa at faa Slesvig: „Vi havde al retten på vor side d. v. s. papirretten; overfor os en modstander, som havde en stor magt og en moralsk ret $i$ den tyske befolknings notoriske misfornøjelse med en dansk regeringsmåde, der ikke magtede de nationale forhold. At han vilde benytte dette måtte jo være soleklart for enhver og var $i$ virkeligheden notorisk for alle. Netop dette udkrævede jo til det yderste den statsmandskløgt at undgå faren, at forberede det uundgåelige offer. Det blev forberedt ved Holstens udskillelse [af Fællesforfatningen i 1858] men ikke ved en 
forlods deling af Slesvig. Hvorfor? fordi man ikke vilde. Regenburg sammenfiltrede det danske og det tyske Slesvig istedetfor at adskille det og forberede Bruddet. Dette er fejlen i dette, den store brøde." Overfor C. C. Halls Tilhænger, fhv. Redaktør C. St. A. Bille udtalte han i 1893 (Hist. Afh. IV S. 132): „Jeg for mit vedkommende har syslet meget og længe med hin tids historie, og jeg har set på den nationale eller nationalliberale politik med større sympati end de fleste af mine samtidige; men jo mere fortrolig jeg er blevet med den, jo mere jeg har fordybet mig i alle hin tids vilkår og bestræbelser, des mere må jeg forbavses, ja forfærdes over Halls og hans politiks sorgløse færd hen over alle farer, hen imod alle de uoverstigelige vanskeligheder, uden at noget blev alvorlig forberedt, enten krigen, der måtte komme, eller den fred, som en gang burde efterstræbes. Det var „det dannede flertals politik“, således omtrent lød -senere forsvaret, en statsmands forsvar for ni års styrelse gennem en række af de mest indviklede, for udenforstående fuldstændig dunkle evolutioner .... vi kommer til at gå i rette med en mand, som påtog sig, hvad han ikke kunde magte, som opgav det retsgrundlag, hvorpå rigets fremtid var bygget, uden at have mod eller evne til at arbejde for et nyt, som var brugeligt, og påvise den vej, vi måtte gå for at nå det ... Jeg tvivler ikke om, at historien vil frakende ham det moralske mod og den $i$ alvor optugtede personlighed, som er nødvendig for statsmanden under så vanskelige forhold.“

Paa Grundlag af det foran meddelte skal jeg gaa over til at paapege de væsentlige Sider i A. D. Jørgensens Virksomhed og Personlighed. Jeg kommer derved til at beskæftige mig en Del med afdøde Dr. phil. Ellen Jørgensens Omtale af ham i Biografisk Leksikon 1937, citeret som „Biografien“.

Det er ikke bestridt, at han ved sit Selvstudium var kommen i fuld Besiddelse af den kildekritiske Metode, og det var forsaavidt for ham som for Kr. Erslev et Maal at finde ud af „wie es eigentlich gewesen“, som den tyske Lærefader har udtryktOpga- 
ven, men Indsamling af teoretisk historisk Viden, naar den ikke tjente en Vurdering af Menneskegruppers eller Enkeltpersoners Livsformer og „Idrætter", var ikke noget, der kunde fange hans Interesse. Det hørte med til hans historiske Anskuelse, som han har udviklet det i en Optegnelse fra 1868, at Folket er historisk i Kraft af et Samliv mellem Slægtleddene de nærmere saavel som de fjernere. Nutiden kan I sig optage det fortidige Liv, og naar Historikeren skifter Ret og Uret mellem "de henfarne", er det ligesaa tilfredsstillende for ham og andre, som hvis det drejede sig om de nulevendes Ret. Naar man nu om Dage betegner ham som Romantiker, kan det berettiges ved denne Delagtiggørelse ved Fantasiens Hjælp i det fortidige. Tydelig kommer Anskuelsen frem $i$ et Brev skrevet paa Indtryk fra Slotsbranden i 1884, hvor han taler om en mangetunget Takkesang, han syntes at høre fra de mange henfarne Slægter, hvis Minde var frelst ved, at Arkivets Papirer undgik Luerne, og fra de ufødte Slægter, som skulde drage Næring af disse minder (Breve Nr. 104). Det endelige Maal for al Indsamling af historisk Viden - og det han for sit Vedkommende ønskede at være i Nærheden af - var for ham netop dette at drage Næring af Minderne. Men saa maatte der altsaa gøres Ret og Skel mellem de henfarne, og naar Dommen gaar imod det hævdvundne, og friske Traade fører op til Nutiden, saa betyder det haard Kamp mod Opinionen. I Redegørelsen S. 164 skrev han: „Det blev mig klart, at dette arbejde efter sin natur måtte vække stor opsigt og bringe mig i en ejendommelig krigstilstand så at sige med hele samtiden. Den retfærdigere bedømmelse af slesvigholstenerne var endda ikke det værste, hertugens biografi blev læst uden indsigelse; man var ligesom resigneret overfor dette spørgsmål. Men da jeg til den ene side angreb Hall (i en replik mod Bille, febr. 1893) og forsvarede Kristian VIII.s nationale politik i Sønderjvlland i modsætning til den senere halsbrækkende fordansk ning, som jeg alt 1883 havde taget afstand fra, til den anden side fremstillede forfatningsforandringen i 1848 som en beklagelig 
overilelse og ophavsmændene som politikere uden dybere historisk sans („Griffenfeld“ og senere $i$ et foredrag i videnskabernes selskab) brod jeg til begge sider i vort politiske samfund. Hele den gamle nationalliberale lejr, hvis ideer endnu råder $i$ de videste kredse, skreg op imod det første, den frisindede ungdom og de radikale mod det sidste.

Det vilde have været flovt, om det ikke havde været så, flovt - for mig, der ikke formåede at slå igennem, og fiovt for samtiden, som ikke kunde afvinde sin nærmeste fortid den interesse at føle sig såret på dens vegne. Kun gennem en grundig forargelse kan min opfattelse have udsigt til at trænge igennem, den skal være en besk lægedrik, ikke en livlig vin.“

Det nye Syn paa Christian VIII var først fremsat 8. September $1894 \mathrm{i}$ et Foredrag i Skibelund Krat ved Højskolernes 50 Aars Jubilæum og fortsattes med en stor Afhandling n. A. i Sønderjydske Aarbøger, hvor et Materiale fremlagdes. I sin Omtale i Historiens Studium i Danmark (1943) S. 214 siger Ellen Jørgensen: „Foredraget vakte megen Kritik; det nye Materiale, der blev fremlagt, overbeviste ingenlunde". Til Dokumentatiòn citeres 4 samtidige Udtalelser, hvoraf to fra de 25-aarige Historikere Aage Friis og P. Munch. Den ved Axel Linvald igangværende fuldstændige Undersøgelse af Christian VIII.s Virksomhed, som den Gang ikke forelaa, vil antagelig klare Sagen. Naar det tilføjes, at „man mente, at det var Jørgensens Tro paa den langsomme organiske Udviklings Ret, der havde præget Billedet", saa er her nævnt en Tanke, han foruden med Hensyn til Junigrundloven havde gjort Anvendelse af paa Enevældens Grundlov Kongeloven. Anvendt paa Junigrundloven vækker denne Mening vistnok ikke mere Anstød, men synes almindelig tiltraadt. Jeg opfatter det i disse Tilfælde ikke saaledes, at der skulde hævdes slet ikke at have været Grundlag for en Reform, tværtimod. Men det stemmer med almindelig Erfaring, at naar en længe sinket og længe ved træg passiv Modstand tilbageholdt Reform omsider baner sig Vej, sker det ofte pludseligt og med 
en vis Ensidighed og uden helt Overblik. Nødvendigheden af at faa en Ende paa Usikkerheden muliggør da Gennemførelse i en Skikkelse, som i Virkeligheden ikke tilfredsstiller, og der er ogsaa Mulighed for, at man forlader sig paa et begavet, men doktrinært Hoved.

Til at gaa imod den stride Modvind og dermed udsætte sig for at blive betragtet som svag i Opfattelsen, mindre fædrelandsk i Følelsen og overdrevent selvbevidst hørte der et borgerligt Mod, men det var til Stede. Det var ogsaa noget, min Far var ret vant til fra ældre Arbejder, der havde ryddet op i historiske Traditioner. Da han i 1887 havde fremskaffet Oplysninger om Christian II.s Fængselsophold paa Sønderborg Slot, der herefter viste sig ikke at have haft den hidtil antagne haarde Karakter, fortalte han, at Carl Ploug havde ytret sin Fortrydelighed over, at Carl Blochs bekendte Maleri saa ikke var historisk korrekt og atter et "historisk Minde" borte. Det kunde jo ogsaa have berøvet Carl Ploug Emnet for et harmfuldt Digt! Men hvor meget stærkere blev der ikke strittet imod, naar det drejede sig om Slægtninge til dem, der kritiseredes. Dagbogen for 24. Oktober 1895 viser et saadant Tilfælde med Protest fra en Datter af den i 1842 afskedigede Statsminister Otto Moltke, der fremkaldte en Tilkendegivelse af Misfornøjelse fra selve Christian IX. og ligeledes Prins Hans (20. Marts 1896). Forst i 1893 var han blevet færdig med det Røre, der rejste sig ved Udgivelsen i 1891-92 af Fru Heibergs Erindringer: „en hel allarm i den litterære Verden“. Da han fandt at maatte forsvare hendes Sandfærdighed overfor Personer, der ansaa sig for gaaet for nær, eller Paarorende af saadanne, maatte han forfatte talrige Indlæg, og hele Udgivelsen med Tilbehør var en vidtløftig Sag. Naar han betegner det som „en mere almindelig og tildels ondartet storm", sigter han til tilbagelagt Polemik med Professor Johannes C. H. R. Steenstrup angaaende Emner af Middelalderens Historie, som han paa et efter sin Mening ikke lodigt Grundlag nødtes af Steenstrup til at vende tilbage til. Steen- 
strup førte som historisk Kritiker i „Dagbladet" et skarpt Sprog (meddelt mig af Professor K. Fabricius med Hensyn til dennes Fars Arbejde om Normannerne) og $i$ et fransk Tidsskrift havde han omtalt Far som Grundtvigianer. Hans Iver for at imødegaa denne førte ham til at skaffe sig Adgang til hans utrykte Bidrag i Brickas Leksikon m. v. At Far ærgrede sig en Del over ham, har han ikke lagt Skjul paa i Redegørelsen S. 148, hvor - som jeg allerede har oplyst $i$ en Artikel i Berlingske Aftenavis for 11. April 1940, Fars Hundredaarsdag - Ordene "denne mand" i Manuskriptet lyder "denne lidenskabelige mand“; vi mente den Gang at afdæmpe Udtrykket. Jeg slutter denne Parentes med at tilføje, at Far derefter for at undgaa Bryderierne valgte Emner af Stedbeskrivelser til Brug for Aarbøgerne og trak sig tilbage fra Leksikonet $\mathrm{m}$. v. Allerede som ungt Menneske havde han jo forestillet sig denne Optræden og et saadant Modsætningsforhold til mange. Da han her egentlig ogsaa førte Ordet paa Sønderjydernes Vegne, var det klart for ham, at han maatte tage Kampen op.

I det foregaaende har jeg udførlig omtalt Forholdene i Hjemmet for at vise, at Far ikke var af de Aandsarbejdere, der for at naa det meste i deres Fag gaar udenom Æ̇teskab cg Familieliv med alle dettes Pligter. Naar en Mand har 6 Born at forsørge og for de flestes Vedkommende at føre frem til den højere Undervisning og Uddannelse, er han solidt forankret 1 det praktiske Livs Opgaver. Der maa være Formodning for, at han ikke besjæles af individualistiske Tendenser og Lyst til at isolere sig, hvilket Indtryk Oplysninger fra hans Ungdom maaske kunde fremkalde. Hertil kommer jeg tilbage. Men i Forbindelse med denne Stilling i Familien vil jeg omtale ham som den gode Økonom. Han var det ogsaa i materiel Forstand. En Del Penge, arvet efter Faderen, var anbragt i Nordiske Telegrafaktier m. v., og Familiens Underhold, der var uden Ekstravagancer, voldte ikke Bekymringer. Men navnlig forstod han at disponere over sin Arbejdskraft og faa det mest mulige ud af den. Paa en Maade 
arbejdede han nok i Perioder, som han selv har beskrevet det, men Tiden mellem disse blev ikke anvendt paa andre forskelligartede Beskæftigelser og Interesser. Den var dels en egentlig Udhvilen, dels en Orientering overfor andre nye Opgaver. Set $i$ Sammenhæng var han derfor i uafbrudt Arbejde udenfor de egentlige Ferier, og man kan sikkert sige for fuld Kraft. Selv under Højtrykket, naar Døren til hans Stue havde været lukket, medens han lod sin fine Hurtigskrift flyve over Papiret med den venstre Haand fingrende i Hageskægget, og han ved Aftensbordẹt tydelig havde Tankerne langt borte, forkortede har, dog ikke sin rigelige Nattesøvn. Travlheden forhindrede ham heller ikke i at føre nødvendige Samtaler eller skrive ofte udførlige Breve, men han afholdt sig fra Samtaler, der var Tidsspilde. Dette sidste giver vistnok Svaret til Louis Bobé, der i "Livsdagen lang“ (1947) S. 142 omtaler ham som Chef i Arkivet og siger, at "hans Væsen var køligt, afmaalt". Han gaar videre og siger, at "hans Elik ikke var frit“, og at han „aldrig har hørt ham le ud“. Dette sidste er vel heller ikke en Chefs Opgave, hans Blik kendes fra Billeder, og naar han til den da højst 30-aarige Bobẻ har fortalt om sine Planer om at skrive en Fremstilling af de dansk-tyske Kulturforbindelser i det 18. Aarhundrede, et Emne, han kunde vente Interesse for hos Bobé, synes han snarest at have været indladende. De forskellige litterære Arbejder er naturligvis bestemt ved Forhold og Omstændigheder, men Arbejder, der med Vilje er blevet opgivne paa Halvvejen, saakaldte Torsoer, efterlod han ikke. Navnet er for Resten mindre træfiende, da Torsoen er et Stykke af et Kunstværk, der har været helt, saa at det manglende med Rette kan tænkes i Harmonı med Torsoen. Men at dette vilde blive Tilfældet ved det litterære Værks Fuldførelse, mangler der Garanti for. Maaske fuldførtes det ikke netop af denne Grund. De Opgaver, der stilledes ham, blev løst og indenfor rimelig Tid. Fra det her anlagte Synspunkt maa det ogsaa ses, naar han om sine egne Oplevelser og Tanker altid havde ført Optegnelser, der sluttelig gik op i Redegørelsen. For 
andre Optegnelser, han havde liggende fra spredt Læsning og tidligere Overvejelser, forstod han efterhaanden at finde Anvendelse, og det vilde være ham ubehageligt, om noget deraf forblev ubrugt. Den enkle og vanebundne Livsførelse var Grundlaget for den fulde Samling om Arbejdsopgaverne.

Disse faldt $i$ to Grupper. Den ene var den folkeoplysende, der omfattede de fleste af hans Skrifter. Her var han Fortæileren, opfyldt af sit Emne og skabende Interesse derfor, tillige paa Vagt overfor ældre Opfattelser og, naar det drejer sig om Fersonligheder, ogsaa paa Vagt overfor Skønmaleriet, der ikke gør Rede for Pletterne i de skildredes Livsførelse og Karakter. Den anden Opgave, der naturnødvendigt maatte fremgaa af den første, var den personlige og sociale Omvurdering. Hovedtilfældet blev for ham Bedømmelsen af den nationalliberale Holdning overfor Enevælden og af dens egen Politik. Naar han gik til Kampen med Modstræben, var det ikke paa Grund af dermed forbundne Ulemper for ham selv, men af indre Aarsager, som han har udtrykt $\mathbf{i}$ sin Betragtning ved Regenburgs Jordefærd i 1895 (Redegørelsen S. 186). (Naar han taler om sine unge Dage, er det Tiden før 1864): „Der må være noget velgørende i uforandret at kunne fastholde sin ungdoms sympatier og antipatier, at leve og dø i overbevisningen om, at det, man sværmede for $i$ de unge dage, var det eneste rette og gode. Det må give selvbevidsthed om troskab og det tilfredsstiller hjertet. Langt vanskeligere er det at leve og udvikles, at skifte syn og opfattelse og dog at bevare forståelsen for det, man engang var betaget af, så man samtidig elsker og dømmer det. Der er et usigeligt vemod heri, man fristes til at sige med Assian: „Happy are they who die in youth!" Lad os dø med den slægt, hvis gerning vi beundrede i vor ungdom, lad os ikke leve for at opgøre regnskabet efter den - "det være hos andre,"."

Medens jeg ikke skal komme ind paa hans Arbejder i Arkivets Tjeneste heller ikke de litterære, hvoraf der var flere, maa jeg berøre den beklagelige saakaldte Arkivstrid mellem Rigs- 
arkivaren og Arkivaren ved Provins (Lands)arkivet i København, hans oprindelig højt skattede Medarbejder Dr. jur. V. A. Secher, da Striden andetsteds er omtalt, nemlig i den af Sechers Søn, Professor Dr. med. Knud Secher besørgede 2. Udgave af Meddelelser om Slægten Secher (Siker) 1939 S. 264-90. Det drejede sig om den indbyrdes Forretningsgang og Kompetence. Der nævnes to Episoder: et Spørgsmaal om Assistentansættelse, hvorom Brev Nr. 317 af 27. Februar 1896 vist er tilstrækkelig oplysende, og et Sporgsmaal om Provinsarkivarens Bortgivelse paa egen Haand af Arkivalier. Et meddelt Brev fra Rigsarkivaren af August 1896 omtaler to saadanne Tilfælde, hvorfor der afæskes Oplysning om mulige andre. Det første af disse Tilfælde, der ikke havde været forelagt, paatales efter Omstændighederne ikke og det andet heller ikke, fordi Sechers eventuelle Fremgangsmaade endnu ikke var afklaret. Den af $\mathrm{K}$. S. fremforte Kritik over, at Chefen dadler uden først at høre, er altsaa ubeføjet. Iøvrigt oplyses det af ham, at Secher, da Minsteriet indhentede Forslag fra Provinsarkiverne om Instruks for deres Forhold til Rigsarkivaren, i August 1896 gjorde Indstilling om den storst mulige Selvstændighed og Uafhængighed for Provinsarkiverne, at Rigsarkivaren i en udførlig Indstilling krævede sin Myndighed opretholdt og erklærede ellers at maatte søge sin Afsked, at han imidlertid kunde erklære sig fuldt tilfreds med den Instruks, der kom ud af Overvejelserne, og at Secher derpaa forlod Arkivtjenesten, hvad han synes i længere Tid at have forberedt sig paa, og 3. Maj 1897 blev Herredsfoged i Nakskov. Den langvarige Spænding dette Mellemværende affødte, for Fars Vedkommende forøget ved, at han af personlige Grunde ikke satte sin Fod i Kultusministeriet, se Brev Nr. 403, angreb ham kendeligt. Da han efter 1-2 Maaneders Sygeleje i Hjemmet 5. Oktober s. A. døde af Lungebetændelse og Hjertelidelse, satte hans Familie de to Ting i Forbindelse med hinanden.

Som straks foran bemærket har der været skrevet adskilligt biografisk om A. D. Jørgensen, se Fortegnelsen i Biografisk 
Leksikon, hvortil senere er kommen P. Lauritsens Bog om ham. Den af Ellen Jørgensen skrevne Biografi paakalder ved sin monumentale Plads særlig Interesse, tillige paa Grund af Forfatterindens anerkendte Sagkundskab, der 1943 ogsaa kom frem i "Historiens Studium," hvor han sammen med Johs. Steenstrup og Kr. Erslev gøres til Genstand for særlig Omtale. Biografien er i det hele baade indtrængende og sympatisk overfor dens Genstand, men adskilligt trænger til nærmere Belysning, hvortil der er samlet Stof i det foregaaende.

Det begynder med den Bemærkning til Redegørelsen, at han „i de sidste Aar under Overspænding og Sygdom havde Forestillingen om, at det var hans Skæbne at maatte bryde med alt og alle og dømme fordums Vejledere og Venner". Til selve „Forestillingen" synes Biografien altsaa at stille sig skeptisk, men Sætningen er urigtig, da han i 1896 var fuldkommen rask. Hvad „Overspænding“ angaar, har han vist aldrig været bedre oplagt, end da han 4. Marts indledte denne selvbiografiske Skildring, og fuldførte den paa 3 Uger vel nok i en alvorlig, men ingenlunde tragisk Stemning. 1896 var netop et roligt Aar, hvad Polemik angaar, og Arkivstriden laa forude. Hvad de vedføjede Stykker fra 1888 og 1895 angaar, var Forholdet et lignende. Naar Biografien har Udtalelser om Lighed med Søren Kierkegaard, er det maaske Opstillingen af en Dialog mellem en Anklager og en Forsvarer og Overskriftens Brug af det ogsaa af S. K. anvendte Udtryk „mit Forfatterskab,“ der har inspireret. Men der er slet ingen Ligh€d mellem „Øjeblikkets“ oprevne Forfatter og A. D. Jørgensens rolige Omtale af sin Opgave og sin Situation, se S. 25. At det kunde trykke at „dømme fordums Vejledere og Venner" (der vedblivende var hans Venner (se S. 32), skulde man tro, en kvindelig Forfatter kunde forstaa.

Endvidere bemærkes det, at "naar han ikke i den sønderjyske Sag traadte frem som Fører, " holdes han foruden ved Hensynet til sit Embede tilbage af Modvilje mod afgørende at bryde med Slægtninge hjemme og Ungdomsvenner, som han trods alle 
nationalpolitiske Modsætninger følte sig knyttet til.Om han ikke var „Fører", kan man faa et Indtryk af ved det foran meddelte; andet Slags Førerskab fandtes i hvert Fald ikke. Hvis hans Embede har spillet nogen Rolle, har den været meget lille. Iøvrigt maa der jo tænkes paa Meningsforskel om den ønskelige Grænsedragning, d. v. s. da ingen vistnok den Gang tænkte Tanker om at indlemme et Sydslesvig til Dannevirke eller Ejderen, om Flensborgs og Omegns Stilling. Hvis dette overhovedet blev terørt paa sønderjydske Møder - jeg husker, at den senere Kektor H. P. Hansen en Gang talte om en Nationalitets naturlige Trang til Udvidelse - saa var det et underordnet Emne, hvorom der ikke agiteredes. Sin Mening om den rette Grænse som Sproggrænsen havde Far udtalt i sin Afhandling, om Dannevirke $1868 \mathrm{og}$ en halv Snes Aar senere overfor Fr. Barfod, se Historiens Studium S. 210. Den var kendt af hans faa Slægtninge i Graasten og Aabenraa, og jeg har aldrig hørt, at de mente noget andet. Vi hørte ham drøfte Flensborg-Spørgsmaalet med K. Kruse, der holdt paa, at det afgørende maatte være Hjertet, der var dansk, omend Tungen talte tysk. Om at „bryde" med hinanden paa dette Grundlag faldt ikke Sønderjyderne ind, og det hele maa betegnes som Fantasi.

Det samme gælder Paastanden om, at han ikke kunde "glemme, at man ikke havde taget Hensyn til ham ved Besættelsen af de historiske Lærerposter efter Allens og Paludan-Müllers Død." Om det første Tilfælde se Redegørelsen S. 128 cg Danske Magasin 7,5, S. 51. Han var kun 31 Aar, og det var velvillige Folk ved Universitetet, der fik ham til at søge. Ogsaa Ministeren Hall var velvillig, men fik lavet en Kombination af Embedsforflyttelser, der endte med, at Rektor C. Paludan-Müller nødtes til at søge Stillingen og fik den. Hertil knyttes følgende Kommentar: „Det var uden al tvivl et stor held for mig, at jeg dengang ikke kom til universitetet; jeg vilde foreløbig vanskelig have kunnet udfylde min plads og jeg har i senere år set langt mere af de uheldige end af de lysere sider ved professor- 
tilværelsen, set fra mit standpunkt. Skulde jeg være gået ind i den, vilde jeg vistnok være bleven meget optagen af lærervirksomheden og spørgsmålet om den historiske undervisning hele landet over." Om hans Respekt overfor Paludan-Müller se Brev Nr. 164. Om det andet Tilfælde, der forelaa 1882, se S. 147. A. D. Jørgensen stod da som den antagelige Efterfølger af den henved 80-aarige Gehejmearkivar C. F. Wegener, men følte sig tillige ifølge sin Interesse for Historieundervisningen tilbøjelig til at søge at blive den ligeledes aldrende Päludan-Müllers Eftermand. I Johs. Steenstrup, der 1882 blev Doktor, „denne universitetets søn", kunde han vente en stærk Konkurrent. Det gik saaledes, ąt Paludan-Müller døde 1. Juni og Wegener afgik 13. December. Af Professorstillingens 6 Ansøgere blev Steenstrup foretrukken, men blandt disse var A. D. Jørgensen $i k k e$, se iøvrigt Brev Nr. 92 til Kr. Erslev. Derved kan vel, ganske bortset fra hans egen citerede Udtalelse, gaas ud fra, at han ikke Resten af sine Dage gik med et Professorkompleks.

I Biografien hedder det videre, at "han altid var paa Vagt overfor Akademikerne“, og at „de, der aandeligt stod ham fjærnest, Erslev, Rubin, Høffding, følte sig tiltrukne og æggede af det fremmedartede og vilde til Bunds i denne Mand, men Jørgensen lukkede sig til overfor den københavnske Intelligens, mens han søgte Selskab med Politikeren Termansen og den fine Kritiker Vodskov, Løsgængere og Eneboere i mere end en Forstand." Det er der ogsaa Grund til at se lidt nærmere paa. Høffding skriver i sine Erindringer (1928) S. 288, at naar han og Far ofte efter sine Moder i sønderjydske Foreninger om Natten vandrede til deres Hjem paa Frederiksberg, kunde hans inderste Tanker undertiden ytre sig, „og de gik baade i militærpolitisk og i religiøs Henseende $i$ andre Retninger end de nationalliberale og konservative Kredse, der tog ham til Indtægt, vilde kunne billige." Her aabnede han sig altsaa. Naar det tilføjes, at „hans Sympati i religiøs" Henseende var hos Katolikkerne, hvad iøvrigt tydeligt mærkes i hans Skildring af Steno", er jeg ikke 
enig i det sidste, og i det første maa ialtfald ikke lægges ind, at han staaende paa Folkekirkens Grund følte sig tiltrukken af katolsk Lære. Formentlig Bogen om Steno havde givet ham Forbindelse med Jesuiterne i København. Jeg husker, at han efter Besøg af en Pater kom ind i Dagligstuen og sagde, idet han ligesom rystede noget af sig, at Pateren i Mørkningen vare blevet t $€$ mmelig indtrængende i sine Udviklinger. For Rubins Vedkomende dementerer de aabenhjertige Breve til ham Biografiens Udtalelse; ncget lignende gælder det smukke Brev Nr. 296 til J. A. Fridericia. Udtalelsen om Termansen og Vodskov og den dertil knyttede Insinuation om Glæde ved splendid isolation falder i det komiske, naar man har kendt Hans Vodskov, min Mors Halvfætter, for hvem Far var Mellemmand med Hensyn til den Finanslovunderstøttelse, hvoraf han levede i sin Ensomhed først i. Virum og fra 1887 i Smaaland og saa at sige kun i brevlig Forbindelse, der ophørte 1892, se Brev Nr. 334. Háns „Væren paa Vagt cverfor Akademikerne“ kan sikkert skænkes Biografien. Iøvrigt henviser jeg til min Skildring af hans Levevis, ligesom Brevudgaven taler sit stærke Sprog.

Det er rigtigt, naar det siges, at Redegørelsen modtages med ringe Forstaaelse og var for uforbeholden for Samtiden, der ikke var venlig efter Angrebet paa Nationalliberalismen og af Antipati mod Fru Heiberg. Det maa imidlertid antages, at Biografien taler $i$ eget Navn, naar det hedder "Den udæskede ved en Selvbeskuelse, at svulmende Overmod og ubarmhjertige Domme“.

Overfor Ellen Jørgensens afholdte Lærer Johs. Steenstrup er „Dommen“ - der dog ikke er en Dødsdom - ganske vist uden Forbehold, cverfor Partierne anføres Undskyldninger, ligesom Forfatteren i Degnets Politik var gaaet Mellemvejen. Omtalen af Barndommens og Ungdommens Læsning, Tanker og Udkast, kan man finde uinteressant, men Bogens Titel indbød til at stifte Bekendtskab bl. a. med hans Udvikling. Det var ikke usund Selvbeskuelse, naar Forfatteren havde taget dette med, for ham var Aandslivet det vigtigste, og han var Romantiker, hvad 
Biografien har givet ham Lov til at være. Det „svulmende Overmod" maa antagelig være, at Forfatteren for sit personlige Vedkommende - hvilket er det springende Punkt - satte andre Former for Aandslivet højere end den historiske Videnskab. Naar dette misforstaas, kan det støde Fagmennesker; talrige Udtalelser viser, hvor klar han var over sin Evnes Begrænsning.

Biografien, der er skrevet uden personligt Kendskab til A. D. Jørgensen, har i nogen Grad gjort ham - i hvert Fald i hans sidste Aar - til en nedbøjet og ikke helt ligevægtig Mand. Vel tyngedes han personlig, og det i 33 Aar, af Hjemstavnens Fraskillelse (og det var maaske dette, der for „den københavnske Intelligens" var det fremmedartede ved ham), men han havde i sig den sønderjydske Styrke og Spændstighed. Han, der ikke oplevede Genforeningen, kunde derfor med Rette udtale det Ønske: „at jeg af og til vil blive nævnt blandt dem, som i tunge tider aldrig mistvivlede om vor frelse." Med disse Ord, som han skrev i 1888, Redegørelsen S. 178, har han bestemt sin historiske Plads som en af dem, der oplevede Fremmedherredømmet og følte sine Opgaver bestemt derved. Og han sammentrænger disse sine Opgaver deri, at han søgte at holde Haabet oppe hos sig og sine Landsmænd. Det var en ideel Brobygning over mod Fremtidslandet, værdifuld for en Eftertid, der lever under Genforeningen og som trænger til at vide, at denne Genforening ikke var noget, der kom af sig selv og fulgte af sig selv. Johan Borups Ord foran. „Jeg kunde fortælle meget om Deres Far", dem kunde jeg gøre til mine, men en Søn maa ikke blive altfor veltalende. Endnu et Træk vil jeg dog føje til min Skildring. Uden sin Hustru, der senere i 391/2 Aar overlevede ham, vilde han ikke være blevet den, han var, ikke fordi hun kunde supplere ham som Historiker, men just som Hustru. 